Филозофски факултет

Универзитет у Новом Саду

shtogod@live.com

\title{
ДА ЛИ ЈЕ ЦАНКАР ЧИТАО МАТОША?
}

У раду се истражују интертекстуалне релације између дела Ивана Цанкара и Антуна Густава Матоша, конкретно Цанкаревог романа На кланцу и Матошеве приповетке Сатао. Рад се бави и поменима Матоша у Цанкаревој кореспонденцији, и покушава да их функционализује у контексту односа поменутих дела, посебно када су у питању шире поетике ова два писца.

Кључне речи: интертекстуалне релације, Антун Густав Матош, мотив љубави, симболика имена, цикличност.

Када су два писца рођена у истој држави, у приближно исто време, као припадници „братских” народа, са животним вековима који се готово преклапају, може се претпоставити да се јесу познавали, или барем чули један за другог, и бар овлаш били упознати са делима која су писали. Тако, може се запазити извесни, додуше површни, паралелизам између хрватског писца Антуна Густава Матоша и словеначког аутора Ивана Цанкара. Матош је рођен 1873. године, а Цанкар 1876. - обојица у Аустроугарској. Нису им блиске само године рођења, већ и смрти: први је преминуо Матош, у загребачкој болници, 1914. године, а четири године касније, и Цанкар, у Љубљани. Више се може закључити када се на уму имају дела ова два аутора настала и објављена у кратком временском размаку: Матош је 1900. године објавио приповетку Камао (Nada; Novo iverje), а Цанкарев роман На кланцу објављен је 1902. године.

Иначе, Цанкар се о Матошу изражавао изразито похвално - у писму Франу Збашнику (датирано 2. јула [1]903. године): „О priliki Vam napišem kaj malega o Matošu in Milčinoviću, edinih hrvaških pisateljih, ki jih sodim lahko z evropskim merilom." ${ }^{39}$ (Cankar 1972: 188). Такође се бринуо о међусобном познавању и упознавању јужнословенских књижевности: том обећању писања о Матошу

\footnotetext{
${ }^{39}$ Што никада није учинио, према напомени с краја књиге (Cankar 1972: 390).
} 
претходи огорчена опаска: „Sploh je svinjarija, kako malo poznamo novejšo hrvaško in srbsko literaturo." (исто: 188), али оно што се у контексту бављења романом На кланцу чини значајним јесте чињеница да је Матици хрватској Иван Цанкар нудио управо тај свој роман (Cankar 1976: 75)

Главни јунак поменуте Матошеве приповетке, Алфред Каменски, једну госпођу инстинктивно препознаје као Фани:

И одиста, Каменскому бијаше тако као ју изврсно познаје, као да ју често и пречесто виђаше, али гдје, гдје?

- Гдје се ми то видјесмо, драга Фани?

- Не знам овчас. А гле, зар се одиста зовем Фани?

- Сӓмо ти о в о име пристаје... (Матош 1969: 47).

Љубавна веза између ликова остварује се на основу ирационалних осећања као што су слутња (,„-Знао сам да ћеш ме чекати, Фани!" (исто: 49)). Наслов другог поглавља поменутог Цанкаревог романа, објављеног две године након Матошеве приповетке, управо је Фани. Ово поглавље бави се љубавном тематиком више него иједно друго у овом роману, баш као што окосницу и Матошеве приповетке чини управо љубавна афера.

Подударност која је у првом плану јесте надимак главних јунакиња: Фани; Јуван и наводи као један од најочигледнијих примера интертекстуалности имена познатих јунака (2013: 230). Док се сама имена минимално разликују, тако различитим женама идентични су надимци који им надевају њихови љубавници: и Francisca de Krystkiewicz, и Францка, у љубави постају Фани. Сем идентичности имена, на исти начин оне и добијају те надимке: Матошев Каменски га својој драгој даје на већ споменути начин, а Цанкарев неименовани уметник, иако му Францка каже своје име (Цанкар 1969: 59), у једном моменту почиње са њом да разговара као да је она његова његова негдашња љубавница којој се увек враћа, ус-

\footnotetext{
${ }^{40}$ И сам Цанкар у том писму - иначе датираном 5. фебруара 1914. године, дакле пре Матошеве смрти - издавање тог свог романа под окриљем Матице хрватске обележава као значајним за боље упознавање двеју култура: „Še drug in važen razlog je bil za to ponudbo. Ako berem hrvaško knjigo, hočem, da je knjiga zares hrvaška. Zato sem prepričan, da bi tudi člani Matice Hrvatske s prav takim zanimanjem brali knjigo, ki je slovenska od prve do zadnje besede, podoba slovenskih ljudi, slovenskih krajev, slovenskega življenja in trpljenja”.

Tako direktno spoznavanje od kulture do kulture, od umetnosti do umetnosti se mi zdi bolj koristno nego vsaka prisiljena antologija." (Cankar 1976: 75).
} 
постављајући однос једнакости између њих две када на Францкино питање о имену те његове некадашње љубави одговори: „Фани, - ти ме питаш како ти је име?” (исто: 62). Чини се да веома брзо успостављен, а веома интензиван љубавни однос између ликова и у приповетки и у роману налази својеврсну материјализацију управо у надимку чијом се употребом обележава почетак блискости. Лакоћа с којом је веза успостављена мотивисана је и осећањем ранијег познанства, које се јавља између и Матошевих и између Цанкаревих заљубљених, будући да оба љубавника својој Фани правдају ранија неверства и моле за опроштај њихове раније одласке (Матош 1969: 53, Цанкар 1969: 62).

Већ је споменуто да постоје велике разлике између две Фани. Једна се чини посебно важном, а тиче се односа њихових љубавника према њиховим рукама. И један и други прво примећују управо руке на њима - односно, потребу за њиховим сакривањем. Каменски прво примећује господску белу рукавицу на гласовиру (Матош 1969: 46), што већ само по себи има симболичну вредност, чак и ако се занемари у контексту успостављања контраста према Цанкаревој Фани чињеница да су руке ове јунакиње касније описане као меке и јаке (исто: 50), а уметник у роману На кланцу готово одмах по успостављању комуникације са Францком примећује њене ружне руке: „Али тако испуцале руке! Кад будеш стајала преда мном сакриј те руке!” (Цанкар 1969: 69). Такође, то што Каменски ставља руке у свилене џепове (Матош 1969: 47) као да налази одјека у једном одбаченом наслову за Цанкарев роман, Свилена марама. Цео тај роман представља споменик мајци ${ }^{41}$, те се не може сметнути с ума ни то што се Каменскоме у смрти јавља управо његова мајка (исто: 63).

Још једна, такође готово узгредна сличност, може се видети у улози коју Америка има у деструирању снова ликова ова два дела. У приповетки Камао, као што је већ речено, са овог света пар љубавника, заједно са њиховом љубављу, шаље управо један Американац. С друге стране, у роману словеначког писца, човек за кога се Францка, главна јунакиња, касније удаје, Тоне Михов, напушта своју породицу и препушта их просјачењу баш под утицајем једне варијанте америчког сна, будући да велики део свог времена пре

\footnotetext{
${ }^{41}$ О чему говори и Јурај Мартиновић (1978: 196-7). Његово карактерисање Францке као митски утемељеног лика донекле се може довести у везу са карактеристичним односом те јунакиње са Матошевом Фани.
} 
одласка проводи читајући о привидно лакшем животу у Америци: „(...) читао сам да у Америци постоји неки човек који има хиљаду ми-ли-о-на...” (Цанкар 1969: 125). Тако, на неки начин, Америка уништава снове јунака и приповетке и романа.

Искуства Цанкаревог уметника у Паризу, о којима он приповеда Францки, наликују бајци и подсећају на опис живота Алфреда Каменског, који баш у у Паризу доживљава једну фантастичну епизоду, где је у Моргу наишао на покојника сасвим сличном себи $)^{42}$ управо као да је започео један нов циклус. У роману На кланцу ти циклуси љубави између уметника и Фани очигледније су обележени као стварна дешавања која се кружно понављају ${ }^{43}$, и у тексту, иако и сам уметник на крају љубави говори Францки: „Заборави, Фани, и опрости ми, онако како си ми увек опраштала. Вратићу се к теби, Фани, кроз месец дана, кроз годину дана, ти добра Фани, ти, моја утешитељице...” (Цанкар 1969: 70), обећавајући понављање циклуса. Описана су два конкретна случаја која су готово идентична: љубав Францке и уметника и љубав Францкине ћерке и уметника - спрам варијанти тог циклуса које су у приповетки Сатао доступна само кроз евоцирана сећања. Оно што је посебно значајно с обзиром на већ представљену необичну важност имена главне јунакиње у Цанкаревом роману јесте епизода у којој Францкина ћерка доживљава судбину своје мајке: наиме, и она носи име Францка ${ }^{44}$. Ипак, не треба да се заборави то да је циклично понављање присутно и у приповетки хрватског писца, иако се не варира љубавни догађај између уметника и Фани, него трагичан исход брачног неверства ${ }^{45}$. Он наступа тек оглашавањем злосутне птице из наслова (Матош 1969: 62), након чега развој догађаја клизи из шака ликова, те се приповетка и завршава готово бесмисленим по-

\footnotetext{
42 "Несретни ноћник бијаше сасвим, ама навлас сличан мени!” (Матош 1969: 55).

${ }^{43}$ Мада ти догађаји нису једини примери цикличности у овом роману. Сама Францка уочава да се доживљаји њеног живота понављају, и препознаје пут којим се враћа, унесрећена у љубави, на крају другог поглавља, као пут којим је узалуд трчала за колима као девојчица, и који симболизује читаву трагику узалудности њеног живота.

${ }^{44} \mathrm{O}$ томе да ова епизода подвлачи немогућност изласка из круга, као и то да се понављањем судбина код деце подвлачи архетипска вредност снова и чежње говори и Јурај Мартиновић (1978: 214, 215, 218).

45 Треба, додуше, подвући да код Матошевог јунака постоји чежња за таквим исходом у животу, о чему нема ни говора код Цанкара. „И Каменски се забринуо, прибојавао, па ипак је тајно жудио таку љубав, таку смрт!” (Матош 1969: 45).
} 
нављањем пакосне птице: „-Фани, Фани, моја драга Фани! Фани, моје гонџе, Фани, слатка мачкице!" (исто: 64) ${ }^{46}$.

Упркос завршетку који није срећан, Матошева приповетка у многоме подсећа на бајку ${ }^{47}$. Док се на неки начин из љубави на груб начин буде у стварност уметник и Францка у роману На кланцу, након што спавају на клупи (Цанкар 1969: 67), иако њен језовити крај изненадно долази, Матошева бајковита приповетка остаје пре критика свакодневице својим царством чудеснога (Katušić 2014: 248). Својим насловом, роман На кланцу успоставља конкретан однос према стварности и њиме се подвлачи димензија друштвене критике у делу. Наиме, као што је већ наведено, првобитни наслов био је Свилена марама, и њиме би се истицала важност мотива чежње (иначе карактеристичан за Цанкара), али је коначни избор изразито социјално наглашен (Мартиновић 1978: 200). Друштвено ангажована књижевност у складу је са Цанкаревим поетичким ставовима из периода непосредно пре објављивања романа: наиме, само дело би требало да делује као критика ${ }^{48}$, у односу и на друштво, и на естетику, и на уметност уопште, више него кроз чланак или фељтон (Митровић 1976: 100) ${ }^{49}$. Негирање ларпурлартизма и залагање за тенденциозну књижевност, везана за овај период (исто: 107), имајући у виду истакнуте додирне тачке Цанкаревог романа - написаног, према Мартиновићу, управо након обрачуна са декаденсом и ,і prihvatanjem društvene stvarnosti

46 Уопште, улога коју крештање птице има у овој приповетки и њена улога у опомињању неверне супруге - сасвим у складу са њеним именом, „Tako se zvaše mistična ptica za koju vjerovahu srednjovjekovni Španjolci da pogiba kada žena prevari muža., како сам Матош вели (1969: 239 само ћирилицом) - подсећа на хор у античкој трагедији.

47 Бернарда Катушић као елементе бајке препознаје многе уметнуте епизоде, између осталог управо и ону „ „згоди” из Каменсковог завичаја, у којој љубоморни муж убија жену, њеног љубавника и себе, као и ону у којој протагониста себе види као покојника на одру (Катушић 2014: 229). Такође, она говори о бајковитости локације у коју су смештени финални догађаји ове приповетке, а на које веома подсећа опис куће у којој уметник у роману На кланцу говори Францки да је била место његове прошле љубави са Фани (смештене баш у Париз): „Становали смо у једној великој старој кући, иза које је био врт, у који никада није крочила туђа нога - ту смо се шетали по месечини, висока трава расла је по уским стазама, дивље убокорени ружини грмови (...)” (Цанкар 1959: 60).

${ }^{48}$ Према Марији Митровић, почевши управо од 1901. и 1902. године, када је Цанкар превео критику у литературу (Митровић 1976: 153).

${ }^{49}$ Слично спомиње и Јурај Мартиновић (1978: 198-9). 
sa svim njenim protivrječnostima, prema kojoj literatura mora izgraditi kritički i aktivistički odnos" (Martinović 1986: 222) - са Матошевом приповетком, чини се коментаром поетике хрватског писца. Тако роман На кланцу добија значај и као роман који би одлично представио Цанкареву поетику у датом тренутку, али и као роман који би уједно био и својеврсна критика дела другог аутора, или барем одговор на његову поетику, посебно када се има у виду да је управо естетизам био од великог значаја за тог другог ${ }^{50}$. Посматрано у контексту приповетке Камао, критика стварности остварена је управо у већ спомињаном злослутном крештању папиге, која својим оглашавањем разбија илузије Фаниног супруга, али и, у последњим редовима, обележава тријумф ужасне стварности над сновима ${ }^{51}$. Када се успостави веза између стварности и папигиног крештања, које је Матош окарактерисао као поклик који следи крв у жилама (Матош 1969: 57), као кострешење које је махнито (исто: 59), бесно дрекање (исто: 59), пакосно крештање (исто: 64), јасним се чини његов став о реалности. Камао тако спада у приповетке у којима се сударају стварност и фантазија, из чега произилази трагичан крај за јунаке (Oraić Tolić 2013: 51, 60). Они сами често не разликују границу између реалног и чудесног, одвојени од стварног света и лишени друштвене позадине (Katušić 2013: 235), и то што су уметници (чак и Фани свира виолончело (Матош 1969: 57)) им се и наплаћује.

Док су код Матоша уметници жртве стварности, код Цанкара постоји двоструко виђење уметника: и као туђинца у свету, и као неког ко тај свет може променити (Martinović 1986: 212), у складу са његовом идејом о важности тенденциозне књижевности. Док је свакако у његовом делу присутна антитеза филистар-уметник (Видмар 1972: 145)52, са јасним симпатијама на страни уметника, Цанкарев поглед на уметника је амбивалентан. Једини уметник у

\footnotetext{
50 Чиме се детаљно бавио Владимир Гвозден (2014: 151-2), цитирајући речи самог Матоша на ту тему: „(...) reakcija proti literarnom industrijalizmu, proti tendencijskom utilitarizmu, proti pokušajima, da umjetnik bude širitelj izvjesnih moralnih i socijalnih ideja na štetu umjetnine, da bude propagator i publicista. Zato je čist artist aristokrat, individualist, indiferentan u moralnim pitanjima, naučan, originalan i protivnik fraze i klišeja, što manje osoban."

${ }^{51}$ Како то означава Анђелка Мијатовић (1973: 142).

52 Ова антитеза добро карактерише разлику између Фаниног мужа, богатог скоројевића, и њеног љубавника, сиромашног уметника, што би могао бити још један разлог да баш ова приповетка буде Цанкару интересантна.
} 
роману На кланцу јесте Фанин вољени, а он је најизразитији појединачни негативни лик у целом делу. Својом несталношћу сличан Матошевом јунаку Каменском, који ,љубљаше само оно што је далеко, недокучиво, чега не имађаше” (Матош 1969: 44), а за Цанкара карактеристичан као лик уметника за кога је сеоска девојка, у њега несрећно заљубљена, само играчка (Видмар 1972: 98-9). Он је тај који безосећајно истиче све сурове детаље стварности, користећи је против једне обичне девојке, не бивајући њоме дотакнут:

- Имао сам ту девојче, с којим сам се шетао поред воде, сваке вечери, - вечери су биле топле и месечина је сијала. Девојче је било глупо, све прљаво и у закрпама...”

- Била је сва поцепана, босе - некакве велике глибаве ноге! - А руке су јој биле сасвим црвене и испуцале. Сишао сам доле к води - тамо је било мирно и пријатно, драга, - и тек што сам је угледао, већ ми је овила руке око врата...

Једном је пошла за мном, као покорно псето је цупкала за мном, о, да си је видела, драга, смејала би се до суза - и унакарадио сам је по својој распусној вољи, и седела је ту читаве дуге сате и гледала у мене тако глупо заљубљено - о, да си је видела, драга! Ја сам се играо с њом и сад сам је одбацио. (Цанкар 1969: 72-3).

Стварност и уметник код Цанкара не стоје супротстављени као код Матоша, већ су, напротив, удружени против обичног човека. Начин на који је представљен уметник и окарактерисано његово третирање обичних девојака јасна је критика уметника-есте$\mathrm{Te}^{53}$, који може да воли и да се бави само чисто лепим, и за кога је радничка класа (чији симбол би биле Францкине испуцале, грубе руке) изван сфере интересовања.

Тако, Цанкарева јунакиња, проста сеоска девојка, критички осветљава Матошеву јунакињу, супротстављајући њој, привилегованој, богатој, негованој и лепој, себе, сиромашну, невољену, запуштену и изнурену, иако лепог лица, истичући удео социјалне позадине у перцепцији лепоте и индиректно оптужујући уметника за подршку таквом виђењу ствари, у исто време налазећи потпору у Цанкаревој широј поетици. Овиме се цитатност функционализује и на значењском и на естетском плану ${ }^{54}$, будући да се различите ци-

\footnotetext{
53 Уметника који би био отуђен од своје људске, човечне суштине, лишен непосредног, слободног и неосмишљеног односа према свету, која га чини склоним ексцесима сваке врсте (Глушчевић 1979: 192-3).
}

${ }^{54}$ О којима говори Јуван (2013: 225). 
татне перспективе, и асимилацијска и дисимилацијска ${ }^{55}$, остварују кроз понављање мотива на другачији начин, чиме се дискретно изражава став једног писца о другом.

Антун Густав Матош и Иван Цанкар живели су и стварали истих година, у оквиру јужнословенских књижевности. Њихова поетичка становишта значајно су се разилазила по питању тенденциозности уметности, јер док је за Матоша карактеристичан естетицизам, Цанкар је веровао у важност критичког односа књижевности према стварности. Ова разлика посебно је истакнута приликом компаративне анализе романа На кланцу и приповетке Камао, који имају неке заједничке тачке ${ }^{56}$, попут поклапања имена главних јунакиња и извесних сличности у љубавним везама у којима се оне налазе - али на мноштву планова и на више начина социјална стварност и стварност уопште обрћу поједине моменте Матошеве приповетке, подвлачећи колику је важност друштвена ангажованост имала за Цанкара с једне стране и делујући као имплицитна критика те приповетке, али и поетике тог аутора уопште.

\section{Извори:}

Антун Густав МАТОШ, 1969: Одабрана дела. Београд: Издавачко предузеће „Рад”.

Иван ЦАНКАР, 1969: На кланцу. Београд: Издавачко предузеће „Рад”.

Ivan CANKAR, 1972: Zbrano delo. Knj. 28, Pisma III. Ljubljana: Državna založba Slovenije (V Ljubljani: Delo).

Ivan CANKAR, 1976: Zbrano delo. Knj. 30, Pisma V. Dodatki. Dopolnila in prepravki. Pregledi. Ljubljana: Državna založba Slovenije (V Ljubljani: Delo).

\section{Литература}

Јосип ВИДМАР, 1972: Прешерн, Цанкар, Жупанчич. Нови Сад: Матица српска (Нови Сад: Будућност).

\footnotetext{
${ }^{55}$ Онако како их Јуван схвата (2013: 242).

${ }^{56}$ Неидентичност мотива не умањује заснованост приче о интертекстуалности, будући да сељење мотива из дела у дело никако није „slično prenošenju kamenja iz razvaline u novu zgradu; motiv je stalno utkan u neki govor, zato se književna dela koja prihvataju tuđi motiv i odazivaju na njega. ”, како вели Јуван (2013: 223).
} 
Vladimir GVOZDEN, 2014: Matošev estetizam. Matoš i Kamov: paradigme prijeloma. Ur. Cvijeta Pavlović, Vinka Glunčić-Bužančić i Andrea Meyer-Fraatz. Split - Zagreb: Književni krug Split - Odsjek za komparativnu književnost Filozofskoga fakulteta Sveučilišta u Zagrebu. 143-187.

Bernarda KATUŠIĆ, 2014: Matoševa modernistička inačica bajke. Anafora I (2014) 2. 225-250.

Juraj MARTINOVIĆ, 1978: Kompoziciona funkcija simbolike u Cankarevom romanu ,Na klancu”. Beograd: Radiša Timotić.

Анђелка МИЈАТОВИЋ, 1973: О једном стилском поступку у новелама А. Г. Матоша. Књижевна историја год. 6, бр. 21. 137-148.

Marija MITROVIĆ, 1976: Ivan Cankar i književna kritika. Beograd: Filološki fakultet (Beograd: Novi dani).

Dubravka ORAIĆ TOLIĆ, 2013: Matoševa proza. Čitanja Matoša. Zagreb: Naklada Ljevak.

\section{Tatjana Kličković}

\section{DID CANKAR READ MATOŠ'S WORK?}

\section{Summary:}

The subject of this paper are the possible intertextual relations between the novel $\mathrm{Na}$ klancu by Slovenian author Ivan Cankar, and the short story Camao by Croatian writer Antun Gustav Matoš. Cankar had mentioned Matoš and Matoš's work in his letters and also attempted to have his novel $\mathrm{Na}$ klancu published by Matica hrvatska. The main similarities between the two works are the nicknames of the female protagonists, who are both called Fanny by their lovers, and their lovers are also artists, although morally incomparable, marking different treatment of the arts. While Matoš believed in independent art and larpurlastism, for which his short story has some similarities with fairytales, Cankar stood for socially engaged art, even choosing a title that focuses on the social meaning of the novel rather than insisting on the motives of yearning and longing, which are very important aspects of his work. The similarities between the work of Cankar and Matoš also point out important poetical differences between the two authors.

Key words: intertextual relations, Anton Gustav Matoš, love motif, name symbolism, cyclicity 